\title{
Gestalt Counseling with Empty Chair Technique to Reduce Guilt among Adolescents at Risk
}

\author{
Yessinta Wahyu Trijayanti ${ }^{1}$, Juntika Nurihsan, Anne Hafina \\ Universitas Pendidikan Indonesia, Indonesia \\ Qyessintawahyu@gmail.com ${ }^{1}$
}

Article Information:

Received April 4, 2018

Revised October 18, 2018

Accepted December 13, 2018

Keywords: guilt; gestalt counseling; empty-chair technique

\begin{abstract}
Adolescent is defined as a period of transitional development from childhood to adulthood. This transition also requires adolescents to make some adjustment. Those who cannot adjust themselves to the transition may induce guilt in them. Guilt is an emotion that follows after a negative behavior. Gestalt counseling with empty chair technique can help counselees finish their "unfinished business", and one of the unfinished businesses is guilt. The research aims to test the effectiveness of Gestalt counseling with empty chair technique to reduce guilt among adolescents at risk. It adopted the quantitative approach with single subject research method. The sample was taken with a purposive sampling technique. The population included 16 adolescents at Yayasan Rumah Tumbuh Harapan in Bandung in 2018, with three adolescents with a high level of guilt as samples. Data were taken using Guilt Instrument. The research employed the A-B design. The results show a significant reduction of guilt based on the mean score in the baseline test and the mean score after the intervention. The mean baseline score of counselee ES was 67.01, and after the intervention, the score fell to 50.19; the mean baseline score of counselee FLO was 85.79 and went down to 76.72 after the intervention, and the mean baseline score of counselee PK was 77.64 and decreased to 63.91 after the intervention. Thus, it can be concluded that Gestalt counseling with empty chair technique is in general effective to reduce guilt.
\end{abstract}

\section{INTRODUCTION}

The adolescent is defined as a period of transition between childhood and adulthood that covers changes in biological, cognitive, and social-emotional (Santrock, 2014). The biological process of adolescent includes changes in the physical nature of individuals. The cognitive process includes changes in the mind, intelligence, and language of the individual. Socialemotional processes include changes in individual relationships with other people, emotions, personality, and the role of social context in development (Santrock, 2014). Biological, cognitive, and social processes are intertwined closely. Social process forms a cognitive process, cognitive process develop or inhibit social process, and biological processes affect the cognitive process.

Transition in life also requires adolescent to be able to adjust. Self-adjustment is a variation of the organism's activities in overcoming an obstacle, satisfying need and establishing a harmonious relationship with the physical and social environment (Chaplin, 1997). Adaptation to the demands and changes of the adolescent as an effective mechanism to overcome stress and avoid psychological crises (Calhoun \& Acocella, 1990). This is because

How to cite:

E-ISSN:

Published by:

Available online:
Trijayanti, Y. W., Nurihsan, J., \& Hafina, A. (2019). Gestalt Counseling with Empty Chair Technique to Reduce Guilt among Adolescents at Risk. Islamic Guidance and Counseling Journal, 2(1). 1-10. https://doi.org/10.25217/igcj.v2i1.302

2614-1566

Institut Agama Islam Ma'arif NU (IAIMNU) Metro Lampung

https://journal.iaimnumetrolampung.ac.id/index.php/igcj 
the adolescent transition period causes many difficulties in adjusting to himself and the environment and development, in essence, is an adjustment effort that is an active attempt to overcome pressure and to find a way out of various problems.

The adolescent has thoughts about "Who am I" which is closely related to self-identity as his uniqueness because adolescent considers that its uniqueness is a great force in their lives. Today adolescents face demands and expectations, as well as dangers and temptations that appear to be more and more complex than those faced by an adolescent at the past (Santrock, 2014). Some adolescents have a positive self-concept and a positive relationship with others so that they can go through childhood into adulthood. However, some teenagers today are faced with a complex lifestyle choice. In America, accidents and suicides among adolescents, drug consumption, juvenile delinquency, and the frequency of pregnancy in adolescent become familiar phenomena. In 1989, 36 of the 1000 girls aged 15-17 in the United States had a baby, $8 \%$ higher than in 1988. The rate of pregnancy in adolescents in the United States is the highest in the western world.

Another behavioral study conducted in Jakarta and Merauke reported that young people have a high enough tendency to engage in activities related to sexual behavior such as kissing, sexual stimulation, masturbation, or even having sex before marriage. In this study focused on adolescent at risk of premarital pregnancy (Hidayangsih, Tjandrarini, Mubasyiroh, \& Suparmi, 2009). The tendency of premarital sexual behavior among adolescent is increasingly occurring, reflected in cases of abortion in Indonesia every year it reaches 2.3 million, 30 percent of which are carried out by adolescent unwanted pregnancy (adverse event) in adolescents shows a tendency to increase between 150,000 and 200,000 cases each year. A survey conducted in nine major cities in Indonesia shows, unwanted pregnancy reached 37,000 cases, 27 percent of which occurred in premarital environments and 12.5 percent were students (Media, 2009). Premarital could causes self-destruction (Hartati, 2018).

The adolescent with very high risk has some problematic behavior and about 10 percent of the adolescent population (Santrock, 2014). Delinquency is associated with early sexual activity, pregnancy at a young age, addictive substance abuse, and the release of a child from school. In his research (Azinar, 2013) said that adolescents today tend to be permissive towards free sex. This is due to the opening of opportunities for courtship activities that lead to free sex. Even though sexual intercourse, even if only once can cause pregnancy during adolescent in the fertile period (Marmi, 2013).

Domestic violence and lack of love from parents make adolescent seeks for love from their male counterparts, thus triggering the onset of sexual intercourse that causes pregnancy (Gyan, 2013). The factors that significantly influence premarital sexual behavior in the adolescent is religiosity, attitude toward sexuality, access, and contact with information media, close friends' attitude and premarital sexual behavior of a close friend (Azinar, 2013). The development of increasingly sophisticated science and technology, including the development of social media has a greater influence on adolescents, one of them is a handphone, with various application facilities that have persuasive abilities in the adolescent. This condition implies that intensive sex education for adolescent, especially at home and at school, that is increasingly important (Indonesia, 2012).

Based on the above explanation it can be concluded that adolescent is at risk of being prone to pregnancy before marriage caused by several factors, including; lack of parental affection, parental domestic violence, close friend influence, low individual religious level, persuasive social media toward sexual behavior, and lack of family sex education.

The negative consequence of free sex, unwanted pregnancy, abortion, psychological distress, and marriage by accident or MBA (Hasan \& Nasma, 2008). It is the risk of stress, depression, quit from school, mistreatment on the baby, feeling alienated because the environment and friend are away (Hanum, 2016). The adolescent who is pregnant at a young 
age and continuing study will be dropout temporarily or so on and can lose what they just started (Safrudin, Kes, Hamidah, \& Kes, 2009).

In the end, the problem of pregnancy in adolescent affects his/herself. The adolescent with an unwanted pregnancy is the problem that causes stress. The main source of stress is a disgrace because of being pregnant without getting married, feeling guilty of abortion, racing at a time because getting pregnant is getting bigger. He will feel increasingly depressed because of fear to convey to parents, excluded from family because of pregnancy, considered abnormal in association (Manuaba, 2001).

Adolescent pregnancy also creates severe psychological consequences (Sampoerna, 1982). Pregnancy in adolescent experiences a sense of inferiority, shame, and feel guilty for having taken actions that are seen as disgrace and sin by religious norms and society. In some cases, pregnant teenagers even make suicidal decisions because they feel very guilty, helpless, depressed, confused and frustrated (Chilman, 1980).

The desire arises to end the pregnancy with abortion and attempted suicide (Nirwana, 2011), feelings of despair, low self-esteem, and self-blame attitude is also related to suicide committed by adolescents on the problem faced (Santrock, 2014). Psychological consequence of adolescent who accompanies suicide, abortion, and does not want to give birth to their children, apparently have a higher guilty feeling (Khisbiyah, 1994). Guilt is a violation of the value system that exists in the general public. Guilt is an introspective emotion which is the result of self-reflection and negative events (Baumeister, Vohs, Nathan DeWall, \& Zhang, 2007).

Guilt is unwanted self-acceptance. Guilt is also a negative emotional state that arises when an individual is at odds with the standardization of behavior that should be (Xu, Bègue, \& Shankland, 2011). Guilt is a negative judgment on oneself in the form of criticism of a specific behavior which includes feeling tense, sorry, sad about the mistakes that have been made, and marked by cursing themselves, over thinking, hoping that he would avoid the mistake that had been done, encourage himself to confess, repair, and apologize (Hastings, Northman, \& Tangney, 2002). Guilt can be shown by the tendency to evaluate negative selfbehavior and behavior improvement (Hastings et al., 2002). Evaluation of negative selfbehavior is characterized by a feeling tense, regret, sadness for the mistakes that have been made, cursing themselves, thinking about problems that are being faced repeatedly, and hoping to cancel the mistakes that have been made.

Behavioral improvement indicated by self-motivation to admit mistakes that have been made, improvement, and apology (Weersing, Weisz, \& Donenberg, 2002). Individual guilt can change individual behavior and ease discomfort (Vangelisti, Daly, \& Rudnick, 1991). The influence of guilt is believed to be an effective control strategy because it leads to a change in the behavior of violater (Ferguson \& Stegge, 1995).

In this view, guilt expresses not only the recognition of an individual mistake but also the evaluation of negative self-behavior. Therefore, in the process of evaluating negative selfbehavior and improvement of behavior violations that have been done, it requires guidance and counseling. Considering that one of the objectives of guidance and counseling is to change individual behavior to achieve a more productive and satisfying life (Yusuf \& Nurihsan, 2006), maintaining and achieving positive mental health so that individual achieves integration, adjustment and positive identification of others, achieving personal effectiveness, and encouraging individuals to be able to make decisions that are important to themselves.

Research on orphanage children has found that orphanage children tended to show difficulties in their social adjustment which reflected the psychological need to be able to adjust the procedures or rules of the environment (Hartini, 2001). The psychological problems experienced by the orphanage children were inferior personality, passive, apathetic, withdrawn, easily discouraged, full of fear and anxiety (Hartini, 2001). 
Some previous researches used empty chair techniques to overcome isolated students (Lestari, 2015), reduced the attitude of being rude (Ramadhani, 2018), and increasing assertive behavior of students bullying victim (Rahmah, 2014), overcoming aggressive behavior (Dyastuti, 2012), intensifying attachment-related sadness and decreasing intensity among suffering from unresolved anger individuals (Narkiss-Guez, Zichor, Guez, \& Diamond, 2015). These researches have examined the effect of using this technique on adolescent maladaptive behaviors. The results show that empty chair techniques can significantly reduce this behavior. However, the study did not specifically and deeply discuss the impact of counseling with an empty chair in overcoming unfinished business, especially in Guilt among Adolescents at Risk.

Therefore, in this study, the researchers focused on the problem of reducing the guilt among adolescents at risk. Based on the background of the researchers described above, the purpose of this study was to examine the effectiveness of gestalt counseling with empty chair techniques to reduce guilt among risky teenagers.

\section{METHODS}

The approach used in this study was a quantitative approach. This approach was used because it has characteristics including the research that describes research problems through a description of the tendency or a need for an explanation of the relationships between variables (Creswell, 2002).

The research method used in this research was single-subject research. The population in this study was adolescent in the Rumah Tumbuh Harapan Foundation in Bandung in 2018; the population consisted of 15 people. The research sample was taken by using purposive sampling technique, in this technique the researcher selects certain elements from the population that will represent or provide information about interesting topics (McMillan \& Schumacher, 2010).

In this study the sample chosen was adolescent with a high level of guilt, there were three people. The research design used was A-B design. The A-B design consists of two conditions, namely baseline, and intervention (Juang, 2005). The A-B design was chosen because it has advantages in the process inside. The basic procedures of $\mathrm{A}-\mathrm{B}$ design see Figure 1.

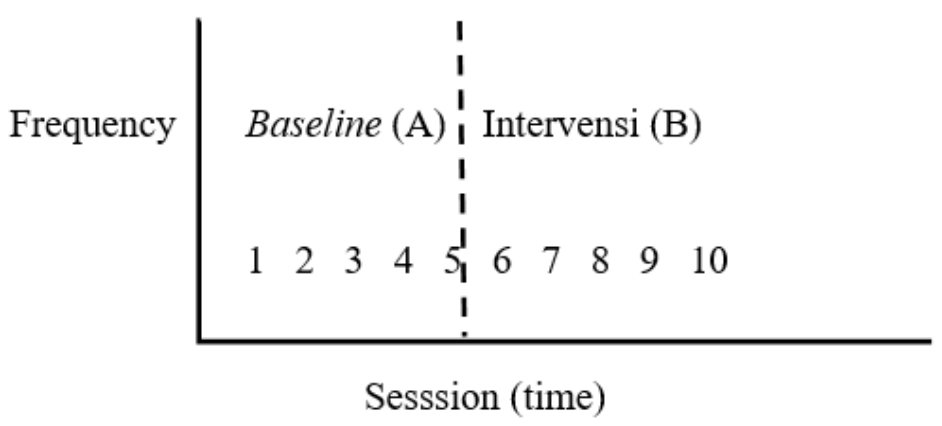

Figure 1. A-B Basic Design Procedure Graph

Guilt brings the individual to focus on their negative behavior towards their victims (Baumeister et al., 2007). The study has supported another research that state guilt focuses on tension and remorse for having done wrong behavior (Sanftner \& Crowther, 1998). The feeling of guilt is a conscious emotion that blames him/herself and regrets for moral violation (Klass, 1988). Guilt is a concept that forms part of a matrix relating to moral division and unification, including a violation of a mistake by blaming self, saddened by a sin that has been committed and regretted (Singh, 2003). Based on the explanation above that aspect of guilt is 
evaluating behavior that violates morals and interpreting the violation by improving it. This conclusion is supported by experts who examine guilt; guilt can be shown by the tendency to evaluate negative self-behavior and behavior improvement (Hastings et al., 2002). Evaluation of negative self-behavior is characterized by a feeling of tension, regret, sadness to the mistakes that have been made, cursing self, thinking about problems that are being faced repeatedly, and hoping to cancel the mistakes that have been made. The behavioral improvement according to is indicated by the self-motivation to admit mistakes that have been made, improvement, and apology (Weersing et al., 2002).

Excessive guilt covers two aspects, namely aspects of evaluating not optimal negative behavior that is not optimal and aspect of improper behavior improvement. The aspect of evaluating negative behavior that is not optimal is characterized by the excessive tense feeling that causes deep fear, deep regret, protracted sadness, cursing oneself for the behavior that has been done, thinking over and over again the mistakes that have been made, and hoping to cancel mistakes that have been made. Improper aspects of improper behavior characterized by not acknowledging mistakes that have been made, so that what is raised is self-defense, efforts to make up for negative behavior that is not responsible, and avoid apologizing to those who have been harmed because of a deep feeling of tension.

The intervention developed to reduce guilt is to use gestalt counseling with empty chair techniques. One of the goals of gestalt counseling is to stimulate counselees to develop their awareness fully, to understand every second, every minute of experience that arises in the counselee's experiential field. The process of gestalt counseling is usually carried out in certain stages consisting of five stages (Joyce \& Sills, 2018). Each stage has its priorities and objectives so that the counselor will always carry out the purpose of counseling by the stages of counseling. The following stages are not basic guidelines, but only a flexible outline for counselors. These stages are First Stage (The Beginning Phase), Second Stage (Clearing The Ground), Third Stage (The Existential Encounter), Fourth Stage (Integration), and Fifth Stage (Ending).

The step to test the validity of item statement was done using statistical processing techniques, namely biserial points correlation. Calculation of item validity statement was done with the help of Microsoft Excel computer program. Instrument reliability is operationally expressed as a correlation coefficient (r) (Saifudin, 2012). To determine the level of reliability of the instrument, testing was done using Cronbach's Alpha $(\alpha)$ formula. Based on the calculation of the instrument reliability test using SPPS, the alpha value was 0.83 from 30 items. Alpha reliability coefficient benchmark with a value of 0.83 was a high degree of reliability.

\section{RESULTS AND DISCUSSION}

The results of the effectiveness study found that Gestalt counseling with empty chair techniques was generally effective for reducing guilt. Research subject showed the change in guilt score after experiencing Gestalt counseling intervention with empty chair techniques. Recapitulation of the effectiveness of Gestalt counseling with empty chair techniques can generally be seen in Table 1 .

The results of the study indicated that the use of Gestalt counseling with empty chair techniques was effective in reducing teenage guilt. This can be seen from the average baseline score decreasing in the mean score of the intervention. The results of the research during the counseling session were as follows. The results of research on ES respondents showed that there was a condemnation of oneself, excessive fear, hoping to cancel the mistakes that have been made. This condition was marked by an attempt to escape from home, for fear of being punished by the family. Escape behavior was part of juvenile delinquency. Juvenile delinquency was behavior that was not socially acceptable until the violation (escape) status 
to crime (Santrock, 2014). This behavior can be caused by peer influence about self-resilience and the influence of low supervision by parents, low support, and application of ineffective discipline. Parenting plays an important role in individual development, one of which instills a sense of guilt to develop a sense of responsibility (Covey, 2014).

\begin{tabular}{cccccc}
\hline $\begin{array}{c}\text { Counselee } \\
\text { Initial }\end{array}$ & $\begin{array}{c}\text { Baseline } \\
\text { (A) }\end{array}$ & $\begin{array}{c}\text { Baseline } \\
\text { Deviation } \\
\text { Standard }\end{array}$ & $\begin{array}{c}\text { Average } \\
\text { Intervention (B) }\end{array}$ & $\begin{array}{c}\text { Intervention } \\
\text { Deviation } \\
\text { Standard }\end{array}$ & $\begin{array}{c}\text { Difference } \\
\text { Average } \\
\text { (A) (B) }\end{array}$ \\
\hline ES & 67,01 & 17,63 & 50,19 & 5,07 & 16,82 \\
\hline FLO & 85,79 & 8,21 & 76,72 & 2,87 & 9,07 \\
\hline PK & 77,64 & 12,14 & 63,91 & 4,95 & 13,73 \\
\hline
\end{tabular}

Table 1. The difference of Average Guilt Score and Deviation Standard at Baseline (A) and Intervention (B)

The second respondent, FLO, showed deep regret, excessive sadness, and repeated thinking about the negative behavior that had been done. This condition was marked by an attempt to commit suicide, abortion, the existence of a mechanism of self-defense against his family with dishonesty over the behavior that had been done to resolve the problem. These efforts were carried out because of the high level of guilt towards his family. Excessive guilt can damage the relationship between one's self toward others, therefore, one's hate themselves (Fisher \& Exline, 2010).

The last respondent, PK showed that there were deep regret and excessive sadness. This condition was marked by attempted suicide and abortion as an effort to solve the problem. These efforts were carried out because of the high level of guilt. The psychological consequence of adolescents who accompany suicide, abortion, and do not want to give birth to their children, apparently have a higher guilty feeling. Excessive guilt (excessive guilt) can develop into maladaptive behavior

The maladaptive behavior caused by high guilt or excessive guilt in this study was the existence of an abortion attempt and has the intention to commit suicide (Dacey, Kenny, \& Margolis, 2000). The adolescent who chooses to commit suicide as an option in overcoming a problem is serious psychological disorders. For most, this is the result of stress, anxiety, and depression, thus experiencing lower problem-solving abilities, never experiencing success, with low academic achievement. Widely published suicide can cause a latent suicidal tendency in adolescent (Moore \& Rosenthal, 2007). Based on the above explanation it can be concluded that adolescent who experienced the consequence of free sex can cause high or excessive guilt so that it can impact maladaptive behavior.

This research provides a new information about how important to help adolescent with guilt in order to prevent the worst possibility it takes. Furthermore, it is useful for counselor or professional mental health care to conduct this approach and technique in this particular circumstance.

\section{CONCLUSIONS}

In general, the level of adolescent guilt at Rumah Tumbuh Harapan foundation in the Academic year 2018 was in the high category. High guilt is characterized by a feeling of tension, deep sadness, self-punishment, deep regret, repetitive mistakes, and hopes to cancel the defeat that has been done, not to admit the mistake done, redeem irresponsible negative behavior, and avoid apologizing.

Gestalt counseling with empty chair techniques effectively reduces guilt in at-risk adolescent. The results showed a decrease in guilt based on the average score results at the baseline and the average score on the intervention. The ES counselee baseline average score 
was 67.01 after being given intervention decreased to 50.19, the counselee FLO baseline average score was 85.79 after being given intervention decreased to 76.72 , and the counselee PK baseline average score was 77. Sixty-four after being given intervention decreased to 63.91. For further researchers, it can be developed about gestalt counseling with empty chair techniques in various backgrounds of life (education, health, social, etc.).

\section{ACKNOWLEDGMENTS}

The authors present their sincere appreciation goes to Dr. Mamat Supriatna, M.Pd. who had given authors inspiration on deciding the topic of this research, Dr. Nurhudaya, M.Pd. as head of guidance and counseling department Universitas Pendidikan Indonesia who had given his expert judgment for the research instrument, Dr. Nandang Rusmana, M.Pd. and Dr. Nandang Budiman, M.Pd. who had given critical advice on this research, and Charles Wong, M.Pd. as head of the institute who allowed researchers to conduct this research at his institute and shared his experience on the same topic of research.

\section{AUTHOR CONTRIBUTIONS STATEMENTS}

YW collected initial data, then formulated a draft of research topic for further study and discussed it with JN and $\mathrm{AH}$. The research started with a detailed investigation of the theories, then formulated instrument blueprint and its items. The instrument then judged by an expert, after several judgments, the instrument was tested for its validity and reliability. After all, researchers arranged the procedures of counseling intervention, giving treatment to the samples and wrote the report of the research. JN evaluated the initial data and careful on every step of the counseling intervention, depth studied on the theory of counseling. AH evaluated the initial data and rechecked data of the research. Every revision of data was always tested carefully. Investigated the theory. Thus, the instrument would appropriate and accurate to measure and answer the research questions.

\section{REFERENCES}

Azinar, M. (2013). Perilaku Seksual Pranikah Berisiko Terhadap Kehamilan Tidak $\begin{array}{llll}\text { Diinginkan. Jurnal Kesehatan } & \text { Masyarakat, }\end{array}$ https://doi.org/10.15294/kemas.v8i2.2639

Baumeister, R. F., Vohs, K. D., Nathan DeWall, C., \& Zhang, L. (2007). How Emotion Shapes Behavior: Feedback, Anticipation, and Reflection, Rather Than Direct Causation. Personality and Social Psychology Review, 11(2), 167-203. https://doi.org/10.1177/1088868307301033

Calhoun, J. F., \& Acocella, J. R. (1990). Instructor's Manual to Accompany Psychology of Adjustment and Human Relationships. McGraw-Hill. Retrieved from Google Scholar

Chaplin, J. P. (1997). Kamus Lengkap Psikologi,(Terjemahan dari Dr. Kartini Kartono). Jakarta: PT. Raja Grafindo Persada. Retrieved from Google Scholar

Chilman, C. S. (1980). Adolescent Pregnancy and Childbearing: Findings from Research. Retrieved from Google Scholar

Covey, S. R. (2014). The 7 habits of highly effective families. St. Martin's Press. Retrieved from Google Scholar

Creswell, J. W. (2002). Educational research: Planning, conducting, and evaluating quantitative. Prentice Hall Upper Saddle River, NJ. Retrieved from Google Scholar 
Dacey, J., Kenny, M. E., \& Margolis, D. (2000). Adolescent psychology (3rd ed.). Cincinnati, $\mathrm{OH}$ : Thomson Learning. Retrieved from Google Scholar

Dyastuti, S. (2012). Mengatasi Perilaku Agresif Pelaku Bullying Melalui Pendekatan Konseling Gestalt Teknik Kursi Kosong. Indonesian Journal of Guidance and Counseling: Theory and Application, 1(1). Retrieved from https://journal.unnes.ac.id/sju/index.php/jbk/article/view/1076

Ferguson, T. J., \& Stegge, H. (1995). Emotional states and traits in children: The case of guilt and shame. In Self-conscious emotions: The psychology of shame, guilt, embarrassment, and pride (pp. 174-197). New York, NY, US: Guilford Press.

Fisher, M. L., \& Exline, J. J. (2010). Moving Toward Self-Forgiveness: Removing Barriers Related to Shame, Guilt, and Regret. Social and Personality Psychology Compass, 4(8), 548-558. https://doi.org/10.1111/j.1751-9004.2010.00276.x

Gyan, C. (2013). The Effects of Teenage Pregnancy on the Educational Attainment of Girls at Chorkor, a Suburb of Accra. Journal of Educational and Social Research, 3(3), 53. https://doi.org/10.5901/jesr.2013.v4n3p53

Hanum, S. M. F. (2016). Dampak Psikologis Pada Kehamilan Remaja (Studi Ekplorasi Di Desa Watutulis Prambon Sidoarjo). Jurnal Kebidanan Midwiferia, 1(2), 93-104. https://doi.org/10.21070/mid.v1i2.353

Hartati, S. (2018). Tazkiyatun Nafs as an Effort to Reduce Premarital Sexual Behavior of Adolescents. Islamic Guidance and Counseling Journal, 1(1), 33. https://doi.org/10.25217/igcj.v1i1.207

Hartini, N. (2001). Deskripsi Kebutuhan Psikologi Pada Anak Panti Asuhan. Insan Media Psikologi, 3(2), 109-118. Retrieved from Google Scholar

Hasan, S., \& Nasma, A. (2008). Let's talk about love. Solo: Tiga Serangkai. Retrieved from Google Scholar

Hastings, M. E., Northman, L. M., \& Tangney, J. P. (2002). Shame, guilt, and suicide. In Suicide science (pp. 67-79). Springer. Retrieved from Google Scholar

Hidayangsih, P. S., Tjandrarini, D. H., Mubasyiroh, R., \& Suparmi, S. (2009). Faktor-faktor yang Berhubungan dengan Perilaku Berisiko Remaja di Kota Makassar Tahun 2009. Indonesian Bulletin of Health Research, 39(2), 88-98. Retrieved from http://ejournal.litbang.depkes.go.id/index.php/BPK/article/view/72

Indonesia, S. (2012). National Population and Family Planning Board (BKKBN), and Kementerian Kesehatan (Kemenkes-MOH), and ICF International. 2013. Indonesia Demographic and Health Survey 2012. Retrieved from https://dhsprogram.com/pubs/pdf/fr275/fr275.pdf

Joyce, P., \& Sills, C. (2018). Skills in Gestalt counselling \& psychotherapy. Sage Publication. Retrieved from Google Scholar

Juang, S. (2005). Pengantar Penelitian Subyek Tunggal. Criced University of Tsukuba. Retrieved from Google Scholar

Khisbiyah, Y. (1994). Konsekuensi Psikologis dan Sosial-ekonomi Kehamilan Tak Dikehendaki Pada Remaja. Populasi, 5(2). https://doi.org/10.22146/jp.12245

Klass, E. T. (1988). Cognitive behavioral perspectives on women and guilt. Journal of Rational-Emotive and Cognitive-Behavior Therapy, 6(1), 23-32. https://doi.org/10.1007/BF01061063 
Lestari, E. S. (2015). Penerapan Konseling Gestalt Dengan Teknik Kursi Kosong Untuk Mengatasi Siswa Terisolir Pada Siswa Kelas VIII SMP 1 Bae Tahun Pelajaran 2013/2014 (PhD Thesis). Universitas Muria Kudus. Retrieved from https://eprints.umk.ac.id/4388/1/HALAMAN_JUDUL.pdf

Manuaba, I. B. G. (2001). Kapita selekta penatalaksanaan rutin obstetri, ginekologi, dan KB. Penerbit Buku Kedokteran EGC. Retrieved from Google Scholar

Marmi. (2013). Kesehatan Reproduksi. Yogyakarta: Pustaka Pelajar. Retrieved from Google Scholar

McMillan, J. H., \& Schumacher, S. (2010). Research in Education: Evidence-Based Inquiry, MyEducationLab Series. Pearson. Retrieved from Google Scholar

Media, K. C. (2009, February 16). 2,3 Juta Kasus Aborsi Per Tahun, 30 Persen oleh Remaja. Retrieved December 11, 2018, from https://regional.kompas.com/read/2009/02/16/11310897/2.3.Juta.Kasus.Aborsi.per.Tahu n..30.Persen.Oleh.Remaja

Moore, S. M., \& Rosenthal, D. A. (2007). Sexuality in adolescent: Current trends. Routledge. Retrieved from Google Scholar

Narkiss-Guez, T., Zichor, Y. E., Guez, J., \& Diamond, G. M. (2015). Intensifying attachmentrelated sadness and decreasing anger intensity among individuals suffering from unresolved anger: The role of relational reframe followed by empty-chair interventions. Counselling Psychology Quarterly, 28(1), 44-56. https://doi.org/10.1080/09515070.2014.924480

Nirwana, A. B. (2011). Psikologi Kesehatan Wanita. Yogyakarta: Muha Medika. Retrieved from Google Scholar

Rahmah, S. (2014). Pengaruh Layanan Konseling Individual Melalui Teknik Kursi Kosong Terhadap Peningkatan Perilaku Asertif Siswa Korban Bullying Kelas XI di SMK AlWashliyah 3 Medan Tahun Ajaran 2014/2015 (PhD Thesis). UNIMED. Retrieved from http://digilib.unimed.ac.id/7825/

Ramadhani, R. P. (2018). Penerapan Teknik Kursi Kosong Dalam Konseling Individu Untuk Mengurangi Sikap Berkata Kasar Siswa di Smp Negeri 5 Kota Jambi. Respository Unja. Retrieved from http://repository.unja.ac.id/3770/

Safrudin, S. K. M., Kes, M., Hamidah, S. P., \& Kes, M. (2009). Kebidanan komunitas. Penerbit Buku Kedokteran EGC. Retrieved from Google Scholar

Saifudin, A. (2012). Reliabilitas dan Validitas, Edisi 4. Yogyakarta: Pustaka Pelajar. Retrieved from Google Scholar

Sampoerna, D. (1982). Pengaruh Perkawinan dan Kehamilan pada Wanita Muda Usia (1st ed.). Jakarta: IAKMII. Retrieved from Google Scholar

Sanftner, J. L., \& Crowther, J. H. (1998). Variability in self-esteem, moods, shame, and guilt in women who binge. International Journal of Eating Disorders, 23(4), 391-397. https://doi.org/10.1002/(SICI)1098-108X(199805)23:4<391::AID-EAT6>3.0.CO;2-D

Santrock, J. W. (2014). Adolescent (15th ed.). New York: Mc. Graw Hiil Companies. Retrieved from Google Scholar

Singh, K. (2003). Rasa Bersalah. Pohon Sukma: Jogjakarta. Retrieved from Google Scholar 
Vangelisti, A. L., Daly, J. A., \& Rudnick, J. R. (1991). Making People Feel Guilty in Conversations. Human Communication Research, 18(1), 3-39. https://doi.org/10.1111/j.1468-2958.1991.tb00527.x

Weersing, V. R., Weisz, J. R., \& Donenberg, G. R. (2002). Development of the Therapy Procedures Checklist: A Therapist-Report Measure of Technique Use in Child and Adolescent Treatment. Journal of Clinical Child \& Adolescent Psychology, 31(2), 168180. https://doi.org/10.1207/S15374424JCCP3102_03

Xu, H., Bègue, L., \& Shankland, R. (2011). Guilt and Guiltlessness: An Integrative Review. Social and Personality Psychology Compass, 5(7), 440-457. https://doi.org/10.1111/j.1751-9004.2011.00364.x

Yusuf, S., \& Nurihsan, A. J. (2006). Landasan Bimbingan \& Konseling. Program Pascasarjana Universitas Pendidikan Indonesia dengan PT Remaja Rosdakarya. Retrieved from Google Scholar 